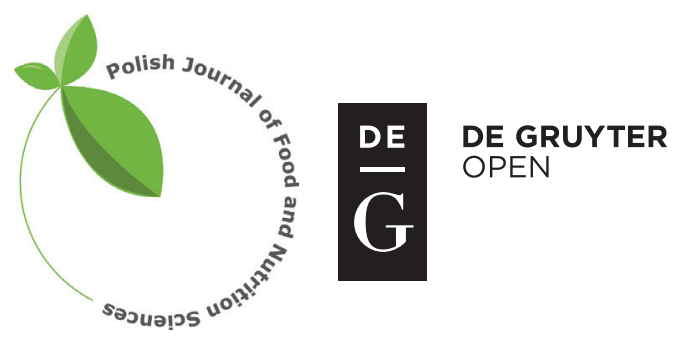

Pol. J. Food Nutr. Sci., 2018, Vol. 68, No. 2, pp. 163-169

DOI: $10.1515 /$ pjfns-2017-0018 http://journal.pan.olsztyn.pl

Original research article

Section: Food Chemistry

\title{
Anti-Glycemic and Anti-Hepatotoxic Effects of Mangosteen Vinegar Rind from Garcinia mangostana Against HFD/STZ-Induced Type II Diabetes in Mice
}

\author{
Naymul Karim, Nutjaree Jeenduang, Jitbanjong Tangpong*
}

\author{
Biomedical Sciences, School of Allied Health Sciences, Walailak University, Nakhon Si Thammarat 80161, Thailand
}

Key words: diabetes, high-fat diet, hepatotoxicity, MVR, oxidative damage

This study focuses on anti-glycemic and anti-hepatotoxic effects of mangosteen vinegar rind (MVR) on five weeks high-fat diet (HFD) / single dose streptozotocin (STZ) $30 \mathrm{mg} / \mathrm{kg} \mathrm{BW}$ induced male ICR diabetic mice. Mice were randomly divided into five groups $(\mathrm{n}=6)$, normal control, diabetic control, and diabetic groups treated with MVR 100, $200 \mathrm{mg} / \mathrm{kg} \mathrm{BW}$ and glibenclamide $60 \mathrm{mg} / \mathrm{kg} \mathrm{BW}$ for one week. After the treatment, lipid profile, glycogen and bilirubin contents, oxidative damage (malondialdehyde, MDA), aspartate aminotransferase (AST) and alanine aminotransferase (ALT) activities, antioxidant enzymes: superoxide dismutase (SOD), catalase (CAT) were measured in plasma and/or liver tissues. MVR and glibenclamide treatment to HFD/STZ-induced diabetic mice significantly reduced their plasma glucose, plasma lipid profile, and hepatic lipid profile $(P<0.05)$. Increased hepatic glycogen content indicates improvement of insulin sensitivity. Moreover, oxidative damage markers were ameliorated in MVR- and glibenclamide-treated groups compared to the diabetic control group. MVR with phenolic compounds content of $75 \mathrm{mg}$ GAE/g dry weight and antioxidant potential of $303 \mathrm{mmol} / \mathrm{L}$ Trolox/g dry weight acted as a hepatoprotective agent against oxidative damage.

\section{INTRODUCTION}

Diabetes is the most common epidemic disease worldwide. In the world, approximately 422 million adult people (up to 2014) are living with diabetes mellitus. Type II diabetes is much more common than type I. Diabetes type II not only affects the adult population, but also children [WHO, 2016]. Diabetes is a metabolic disorder, which is correlated with abnormalities of glucose, lipid and protein homeostasis [Van den Berghe et al., 2006]. High glucose levels generate reactive oxygen species (ROS) in the body via several pathways, such as glucose autoxidation, the polyol pathway and production of advanced glycation end products [Bonnefont-Rousselot, 2002]. Increased ROS production leads to cellular and organ damage including the liver, kidney and pancreas by lipid peroxidation and reduced antioxidant enzyme activity [Das \& Sil, 2012]. The liver is a large organ of the body which plays a major role in lipid metabolism, glucose homeostasis and stores glucose as glycogen [Nguyen et al., 2008]. Increased aspartate aminotransferase (AST) and alanine aminotransferase (ALT) activities are liver injury biomarkers and are higher in diabetics [Sivakrishnan \& Kottaimuthu, 2014]. Liver plays a significant role in blood glucose homeostasis via uptaking elevated concentration of glucose from blood and its storage as glycogen; and additionally produces glucose for circulation by glycogenolysis under starvation conditions [Sherwin, 1980]. In type II diabetes, glucose uptake decreases via a glu-

\footnotetext{
* Corresponding Author: E-mail: njibjoy@yahoo.com (J. Tanpong) oxygartanin, $2.84 \%$ garcinon E, and $3.22 \%$ other xanthones.

cose transporter due to insulin resistance, and glucose output is increased ultimately decreasing glycogen content [Wilcox, 2005]. There is an available medication for type II diabetics such as metformin which has been reported to have an adverse effect on liver disease [Miralles-Linares et al., 2012]. It is important to find out which alternative therapeutic and natural herbs are the best and with fewest adverse effects [Pandey et al., 2011]. Phenolic compounds have potent antioxidant capacity and can scavenge generated ROS from our body. Phenolic compounds are found in many natural herbs and are a source of alternative medicine for diabetes and other metabolic diseases [Pandey \& Rizvi, 2009]. A previous study has proved that aqueous extract of mangosteen vinegar rind (MVR) from Garcinia mangostana is rich in polyphenolic compounds and possesses antioxidant activity [Phyu \& Tangpong, 2014].

The aim of this study was to investigate the anti-glycemic and anti-hepatoprotective effects of MVR against HFD/STZ-induced diabetes in mice.

\section{MATERIALS AND METHODS}

\section{Chemicals and reagents}

Mangosteen vinegar rind (MVR), which is a one-year fermented pure rind extract from Garcinia mangostana, was supplied from Asia \& Pacific Quality Trade Co., Ltd. (Bangkok Office), Thailand. MVR contains $69.01 \%$ alpha mangosteen, $17.85 \%$ gamma mangosteen, $4.13 \%$ gartanin, $2.95 \%$ 8-de- 
This product was freeze dried under vacuum at $-80^{\circ} \mathrm{C}$ for $18 \mathrm{~h}$ using an evaporator and the \% yield was calculated. Analytical grade chemicals were used for analysis which were purchased from Sigma-Aldrich Chemical Co. (St. Louis, MO, USA), Merck \& Co. (Germany) and Millipore Corporation (Billerica, MA, USA) while glibenclamide was purchased from the government pharmaceutical organization (GPO, Thailand).

\section{Total phenolics content and total antioxidant capacity of MVR}

Total phenolics content of MVR was evaluated by the Folin-Ciocalteu's method [Kaisoon et al., 2011]. Briefly, $12.5 \mu \mathrm{L}$ of MVR of different concentrations $(0.1-1.0 \mathrm{mg} / \mathrm{mL})$ and the control (water, instead of MVR) were added to a 96well microplate followed by $12.5 \mu \mathrm{L}$ of Folin-Ciocalteu's phenol reagent. After $5 \mathrm{~min}, 125 \mu \mathrm{L}$ of a $7.5 \%$ sodium carbonate $\left(\mathrm{Na}_{2} \mathrm{CO}_{3}\right)$ solution was added to the mixture, which was left for $30 \mathrm{~min}$. Then, its absorbance was recorded at $765 \mathrm{~nm}$ using a microplate reader (Multiskan GO, Thermo Fisher Scientific, Waltham, MA, USA). Gallic acid $(0-100 \mathrm{mg} / \mathrm{L})$ was used as a standard. The total phenolics content was calculated on the basis of response linear regression obtained from the curve of the standard and expressed as the gallic acid equivalents per g dry weight of MVR (mg GAE/g dry weight).

Total antioxidant capacity of MVR was determined by the ABTS assay [Re el al., 1999]. ABTS ${ }^{*}$ was produced by reacting $7 \mathrm{mmol} / \mathrm{L}$ ABTS in $\mathrm{H}_{2} \mathrm{O}$ with $4.9 \mathrm{mmol} / \mathrm{L}$ potassium persulfate $\left(\mathrm{K}_{2} \mathrm{~S}_{2} \mathrm{O}_{8}\right)$, stored in the dark for $12-18 \mathrm{~h}$. The $\mathrm{ABTS}^{\cdot+}$ solution was diluted to give an absorbance of $0.750 \pm 0.025$ at $734 \mathrm{~nm}$. Briefly, $180 \mu \mathrm{L}$ of the ABTS ${ }^{\cdot+}$ solution was added to $20 \mu \mathrm{L}$ of different concentrations of MVR $(0.1-1.0 \mathrm{mg} / \mathrm{mL})$. The absorbance was recorded at $734 \mathrm{~nm}$ and the extent of decolonization was calculated as a percentage reduction in absorbance. Different concentrations of Trolox were used for constructing the standard curve, and the total antioxidant capacity was expressed as $\mathrm{mmol} / \mathrm{L}$ of Trolox equivalent per gram of dry weight ( $\mathrm{mmol} / \mathrm{L}$ Trolox/g dry weight).

\section{Maintenance of animals}

Fifty-four ICR adult male mice (6 weeks old, 25-30 g) were purchased from the National Laboratory Animal Center, University, Salaya district, Nakhon Pathom. The animals were allowed access to water and food ad libitum one week before the start of the treatment with a constant room temperature of $23 \pm 2^{\circ} \mathrm{C}$, relative humidity of $55 \pm 10 \%$, ventilation and a $12 \mathrm{~h} \mathrm{light/dark} \mathrm{cycle} \mathrm{[Jarukamjorn} \mathrm{et} \mathrm{al.,} \mathrm{2011].}$ Experimental animal protocols were approved by the Animal Care and Use Committee of the Walailak University (No.002/2015).

\section{Study design}

Mice were divided into two groups, the control group $(n=6)$ received a normal diet while the groups fed a high-fat diet $(n=24)$ received high-fat food (60\% normal diet, $12 \%$ lard oil, $12 \%$ sugar, $8 \%$ yolk powder, $6 \%$ peanut powder, $1 \%$ milk powder, and $1 \%$ water) for up to five weeks. After five weeks, diabetes was induced by intraperitoneal streptozotocin injec- tion (STZ, $30 \mathrm{mg} / \mathrm{kg} \mathrm{BW}$ ) to overnight fasted high-fat fed mice (diabetic mice, DM). MVR at doses of 100, $200 \mathrm{mg} / \mathrm{kg}$ BW and glibenclamide at $60 \mathrm{mg} / \mathrm{kg} \mathrm{BW}$ were orally administered at 8.00-9.00 am for one week. The experiments were broken into independent groups ( $\mathrm{n}=6$ per group) as follows:

- Group 1: Untreated normal control (received normal saline)

- Group 2: Diabetic control (received normal saline)

- Group 3: DM+ MVR (100 mg/kg BW)

- Group 4: DM + MVR (200 mg/kg BW)

- Group 5: DM+ glibenclamide $(60 \mathrm{mg} / \mathrm{kg}$ BW).

\section{Sample collection}

After the treatment, mice from all groups were fasted overnight and anesthetized by sodium nembutal $(65 \mathrm{mg} / \mathrm{kg}$ BW). Blood was obtained via a left ventricular puncture and perfused with ice-cold saline, $\mathrm{pH}$ 7.4. The liver was collected and preserved at $-30^{\circ} \mathrm{C}$ for further analysis. The liver tissue was homogenized in cold $0.1 \%$ TCA solution, $10 \%$ $\mathrm{HClO}_{3}$ and $\mathrm{PBS}, \mathrm{pH} 7.4$, using protease inhibitors (leupeptin, pepstatin, and aprotinin) prior to centrifugation at $13,500 \times \mathrm{g}$ for $15 \mathrm{~min}$ at $4^{\circ} \mathrm{C}$, and the supernatant was separated for analysis.

\section{Biochemical assay}

Plasma glucose, lipid profile (triglyceride (TG), total cholesterol (TC), high density lipoprotein (HDL), low density lipoprotein (LDL), liver function test (aspartate aminotransferase (AST), alanine aminotransferase (ALT), total bilirubin) were examined using commercially automated chemicals from Biosystems (Costa Brava, Barcelona), Stanbio Laboratory (Boerne, USA) and Thermo Scientific (Waltham, MA USA) using photometric methods. Lipids were extracted from the liver tissue using the Bligh \& Dyer extraction method [Bligh \& Dyer, 1959]. Afterwards, $0.4 \mathrm{~mL}$ of extracted lipids were placed in a glass tube and $0.5 \mathrm{~mL}$ of $2 \%$ triton X-100 in chloroform was added. The mixture was evaporated in the dryer at $55-60^{\circ} \mathrm{C}$ and resolved in $0.5 \mathrm{~mL}$ of deionized water. Then, the sample was incubated at $37^{\circ} \mathrm{C}$ for 15 min using a shaking water bath. The contents of triglycerides and cholesterol with its fractions were measured using a Stanbio Laboratory (Boerne, USA) reagent kit [Carr et al., 1993].

\section{Determination of oxidative stress and antioxidant markers}

The malondialdehyde (MDA) levels of plasma and liver tissue were measured as a lipid peroxidation marker according to previously described methods [Ceci et al., 2014; Goulart et al., 2005]. The antioxidant enzyme defense system markers, superoxide dismutase (SOD) and catalase (CAT), from the liver tissue were measured by the pyrogallol autoxidation [Marklund \& Marklund, 1974] and $\mathrm{H}_{2} \mathrm{O}_{2}$ decomposition methods [Takahara et al., 1960].

\section{Determination of liver tissue glycogen content}

Liver tissue glycogen was extracted following Bennett et al. [2007] with a slight modification. Concisely, $100 \mathrm{mg}$ of liver were homogenized in $1 \mathrm{~mL}$ of $10 \% \mathrm{HClO}_{3}$ and sonicated for $1 \mathrm{~min}$. The mixture was centrifuged at $13,500 \times \mathrm{g}$ for $15 \mathrm{~min}$ 
and separated from the supernatant into new tubes. The resultant pellet was homogenized again in $1 \mathrm{~mL}$ of $10 \% \mathrm{HClO}_{3}$ using a sonicator for $1 \mathrm{~min}$. After centrifugation at $13,500 \times \mathrm{g}$ for $15 \mathrm{~min}$, the supernatant was added to the previous supernatant. Then, $2.5 \mathrm{~mL}$ of ethanol was properly mixed with the supernatant and centrifuged at $3000 \times \mathrm{g}$ for $15 \mathrm{~min}$. The supernatant was carefully discarded and the glycogen was resolved in $1 \mathrm{~mL}$ of distilled water. The total glycogen content was measured following the phenolsulfuric acid method using a microplate reader (Multiskan GO, Thermo Fisher Scientific, Waltham, MA, USA) [Bennett et al., 2007; Masuko et al., 2005].

\section{Statistical analysis}

The data are expressed as mean \pm standard error of the mean (SEM); differences were considered to be statistically significant at $P<0.05$. Data were analyzed by one-way analysis of variance (One-way ANOVA) and multiple comparisons of groups were done by Tukey's post hoc test using a commercially-available statistic software package (SPSS for Windows, V. 17.0 Chicago, USA).

\section{RESULTS}

\section{Total phenolic content and total antioxidant capacity of MVR}

The content of total phenolics of MVR was $75 \pm 1.7 \mathrm{mg}$ GAE/g dry weight. MVR was characterized by the scavenging activity against $\mathrm{ABTS}^{\cdot+}$. Total antioxidant capacity of MVR was $303 \pm 20 \mathrm{mmol} / \mathrm{L}$ Trolox $/ \mathrm{g}$ dry weight. The antioxidant capacity of rind extract is comparatively higher that of the other pants of mangosteen [Lim et al., 2013].

\section{Effect of MVR on mice body weight and plasma glucose level}

Mice were fed with HFD for five weeks and a single dose STZ (IP) $30 \mathrm{mg} / \mathrm{kg}$ BW led to significantly $(P<0.05)$ increased mice body weight compared to the normal control. However, one-week treatments were able to reduce HFD-induced mice

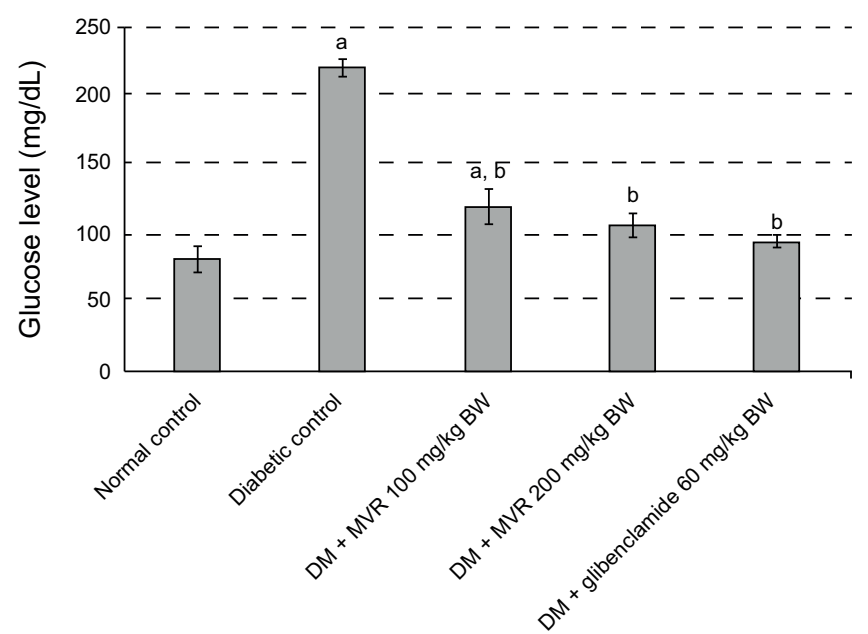

FIGURE 1. Glucose level in HFD/STZ induced type 2 diabetic mice (DM) model. Data are expressed as mean $\pm \operatorname{SEM}(n=6)$. ${ }^{\mathrm{a}} P<0.05$ versus Normal control; ${ }^{\mathrm{b}} \mathrm{P}<0.05$ versus Diabetic control.
TABLE 1. Effect of mango vinegar rind (MVR) on mice body weight (BW) before and after treatment.

\begin{tabular}{lccc}
\hline Group & Before & After & $\begin{array}{c}\text { Weight } \\
\text { gain }(\%)\end{array}$ \\
\hline Normal control & $41 \pm 0.7$ & $42 \pm 0.7$ & 2.20 \\
Diabetic control & $51 \pm 2.9^{\mathrm{a}}$ & $51 \pm 1.7^{\mathrm{a}}$ & 1.50 \\
$\begin{array}{l}\mathrm{DM}+\mathrm{MVR} \\
100 \mathrm{mg} / \mathrm{kg} \mathrm{BW}\end{array}$ & $48 \pm 1.8^{\mathrm{a}}$ & $48 \pm 1.2^{\mathrm{a}}$ & -0.42 \\
$\mathrm{DM}+\mathrm{MVR}$ & $50 \pm 1.0^{\mathrm{a}}$ & $50 \pm 1.1^{\mathrm{a}}$ & -0.04 \\
$\begin{array}{l}\text { O } \\
\mathrm{DM} / \mathrm{kg} \text { BW }\end{array}$ & $50 \pm 2.0^{\mathrm{a}}$ & $48 \pm 1.8^{\mathrm{a}}$ & -4.62 \\
$60 \mathrm{mg} / \mathrm{kg} \mathrm{BW}$ & &
\end{tabular}

DM - diabetic mice. Data are expressed as mean \pm SEM $(n=6)$. Data were analyzed by one-way analysis of variance (ANOVA) followed by the Turkey's post hoc test. ${ }^{a} P<0.05$ versus Normal control.

body weight (Table 1). Similarly, mice belonging to HFD/STZ $30 \mathrm{mg} / \mathrm{kg}$ BW group had a significantly $(P<0.05)$ higher plasma glucose than the control group. MVR 100, $200 \mathrm{mg} / \mathrm{kg} \mathrm{BW}$ and glibenclamide $60 \mathrm{mg} / \mathrm{kg}$ BW treatments led to the diabetic mice having significantly $(P<0.05)$ reduced glucose levels as shown in Figure 1.

\section{Effect of MVR on glycogen content}

Liver glycogen storage showed less tissue resistance. In this study, the diabetic control group had a significantly $(P<0.05)$ lower glycogen content in their liver tissue compared to the normal control group. However, MVR 100, $200 \mathrm{mg} / \mathrm{kg}$ BW and glibenclamide $60 \mathrm{mg} / \mathrm{kg}$ BW treatments showed a significantly $(P<0.05)$ improved glycogen content in the diabetic mice, which was indicative of improved insulin sensitivity compared to the diabetic control (Figure 2).

\section{Effect of MVR on plasma and hepatic lipid profile}

In comparison with the normal control group, the HFD/ STZ-induced diabetic groups showed significantly $(P<0.05)$ higher TC, TG, LDL levels and lower HDL level. Treatment

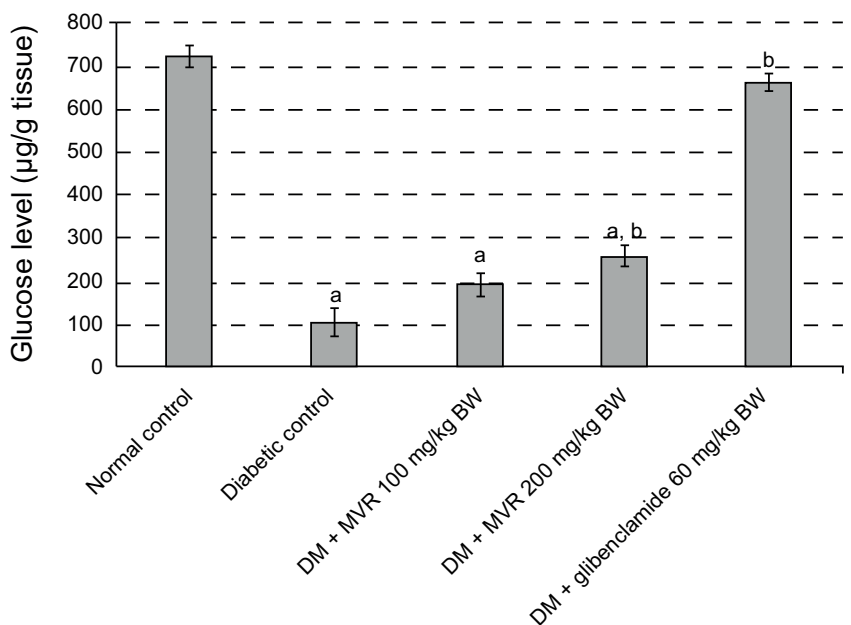

FIGURE 2. Glycogen content in diabetic mice (DM) treated with MVR $100,200 \mathrm{mg} / \mathrm{kg} \mathrm{BW}$ and glibenclamide $60 \mathrm{mg} / \mathrm{kg}$ BW. Data are expressed as mean \pm SEM $(n=6) .{ }^{a} P<0.05$ versus Normal control; ${ }^{b} P<0.05$ versus Diabetic control. 
TABLE 2. Effects of mangosteen vinegar rind (MVR) on plasma and hepatic lipid profile of mice model.

\begin{tabular}{l|c|c|c|c|c|c}
\hline \multirow{2}{*}{ Group } & \multicolumn{4}{|c|}{ Plasma } & \multicolumn{2}{c}{ Liver tissue } \\
\cline { 2 - 7 } & TC (mg/dL) & TG (mg/dL) & HDL (mg/dL) & LDL (mg/dL) & TC (mg/dL) & TG (mg/dL) \\
\hline Normal control & $120 \pm 8.3$ & $48 \pm 3.3$ & $34 \pm 2.2$ & $74 \pm 4.5$ & $175 \pm 5.8$ & $67 \pm 7.8$ \\
Diabetic control & $240 \pm 7.6^{\mathrm{a}}$ & $94 \pm 2.2^{\mathrm{a}}$ & $23 \pm 0.7^{\mathrm{a}}$ & $198 \pm 7.3^{\mathrm{a}}$ & $227 \pm 1.3^{\mathrm{a}}$ & $202 \pm 9.4^{\mathrm{a}}$ \\
DM+MVR 100 mg/kg BW & $225 \pm 3.6^{\mathrm{a}}$ & $68 \pm 1.0^{\mathrm{a}, \mathrm{b}}$ & $25 \pm 0.7^{\mathrm{a}}$ & $186 \pm 3.3^{\mathrm{a}}$ & $222 \pm 5.2^{\mathrm{a}}$ & $128 \pm 4.2^{\mathrm{a}, \mathrm{b}}$ \\
DM+MVR 200 mg/kg BW & $180 \pm 5.1^{\mathrm{a}, \mathrm{b}, \mathrm{c}}$ & $60 \pm 4.7^{\mathrm{b}}$ & $28 \pm 0.7^{\mathrm{b}}$ & $140 \pm 5.5^{\mathrm{a}, \mathrm{b}, \mathrm{c}}$ & $212 \pm 7.0^{\mathrm{a}, \mathrm{b}}$ & $103 \pm 4.6^{\mathrm{a}, \mathrm{b}, \mathrm{c}}$ \\
DM+glibenclamide 60 mg/kg BW & $132 \pm 6.9^{\mathrm{b}}$ & $53 \pm 3.7^{\mathrm{b}}$ & $34 \pm 1.0^{\mathrm{b}}$ & $88 \pm 7.3^{\mathrm{b}}$ & $180 \pm 7.7^{\mathrm{b}}$ & $74 \pm 4.7^{\mathrm{b}}$ \\
\hline
\end{tabular}

DM - diabetic mice; TC - total cholesterol; TG - total triglyceride; HDL - high density lipoprotein; LDL - low density lipoprotein. Data are expressed as mean \pm SEM $(n=6) .{ }^{\text {a }} P<0.05$ versus Normal control; ${ }^{b} P<0.05$ versus Diabetic control; ${ }^{c} P<0.05$ versus MVR-treated at dose $100 \mathrm{mg} / \mathrm{kg}$ BW.

TABLE 3. Effect of mangosteen vinegar rind (MVR) on liver function markers of mice model.

\begin{tabular}{lcc}
\hline Group & ALT $(\mathrm{U} / \mathrm{L})$ & AST $(\mathrm{U} / \mathrm{L})$ \\
\hline Normal control & $36 \pm 3.8$ & $57 \pm 2.3$ \\
Diabetic control & $86 \pm 5.8^{\mathrm{a}}$ & $96 \pm 3.1^{\mathrm{a}}$ \\
DM+MVR $100 \mathrm{mg} / \mathrm{kg} \mathrm{BW}$ & $56 \pm 3.1^{\mathrm{a}, \mathrm{b}}$ & $83 \pm 6.9^{\mathrm{a}}$ \\
DM+MVR 200 mg/kg BW & $51 \pm 1.7^{\mathrm{b}}$ & $69 \pm 1.7^{\mathrm{b}}$ \\
DM+glibenclamide 60 mg/kg BW & $39 \pm 2.5^{\mathrm{b}}$ & $61 \pm 0.9^{\mathrm{b}}$ \\
\hline
\end{tabular}

DM - diabetic mice; ALT - alanine aminotransferase; AST - aspartate aminotransferase. Data are expressed as mean \pm SEM $(n=6)$. ${ }^{\mathrm{a}} P<0.05$ versus Normal control; ${ }^{\mathrm{b}} P<0.05$ versus Diabetic control.

with MVR 100, $200 \mathrm{mg} / \mathrm{kg}$ BW and glibenclamide $60 \mathrm{mg} /$ $\mathrm{kg}$ BW to the diabetic mice significantly $(P<0.05)$ improved the lipid profile in plasma and liver tissue (Table 2).

\section{Effect of MVR on plasma liver function test}

The liver function markers (ALT and AST) of male ICR mouse were consistently significantly $(P<0.05)$ higher than in the normal control group (Table 3). When compared with the HFD/STZ-induced diabetic group, MVR 100, $200 \mathrm{mg} / \mathrm{kg}$ BW and glibenclamide $60 \mathrm{mg} / \mathrm{kg}$ BW treatments significantly $(P<0.05)$ attenuated the hepatocellular damage markers ALT and AST.

\section{Effect of MVR on oxidative stress marker and antioxidant enzymes activity}

The lipid peroxidation of plasma and liver tissue reported as the malondialdehyde content (MDA) was significantly $(P<0.05)$ higher in the diabetic group compared to the normal control group. Moreover, the bilirubin level in plasma and SOD and CAT activities in liver tissue were significantly $(P<0.05)$ lower in the diabetic group compared to the normal control group. However, MVR and glibenclamide significantly $(P<0.05)$ improved both antioxidant enzymes activity and MDA levels in plasma and liver tissue compared to the diabetic control group as shown in Table 4.

\section{DISCUSSION}

The present study provides evidence that MVR shows remarkable anti-glycemic and anti-hepatotoxic effects by improving plasma glucose levels, lipid metabolism, hepatic glycogen content and hepatic antioxidant systems in HFD/ STZ-induced type II diabetic mice. These mice had impaired insulin sensitivity with greater insulin secretion to compensate for elevated blood glucose levels similar to the obese human phenotypic condition. A low dose of streptozotocin partially destroys the pancreatic beta cell and reduces insulin secretion. Both HFD and STZ produced non-genetic and a comparatively less expensive type II diabetic model, giving effects similar to type II diabetes in human patients [Gilbert et al., 2011].

In vitro and in vivo studies have proven that Garcinia mangostana is characterized by antioxidative and cytoprotective activities due to the presence of phenolic compounds [Phyu \& Tangpong, 2014; Sattayasai et al., 2013]. Several studies found that the polyphenolic compounds found in Aegle marmelos, Commiphora mukul, green tea, cinnamon and ginger have hepatoprotective properties in different animal models [Elgawish et al., 2015; Ismail, 2014; Ramesh et al., 2015; Suriyamoorthy et al., 2014]. HFD/STZ induction produces high glucose levels in diabetic mice [Li et al., 2014], leading to oxidative damage and induced hepatotoxicity [Berdja et al., 2016; Cordero-Herrera et al., 2015]. In this study, HFD/ STZ-induced diabetic model had significantly $(P<0.05)$ higher glucose levels than the normal control group. However, the MVR is able to reduce plasma glucose significantly $(P<0.05)$ compared to the diabetic control group (Figure 1) due to the presence of phenolics which show free radical scavenging activity. Morin, a flavonoid was shown to display the antioxidant activity against high-glucose-induced oxidative stress by mediating apoptosis in primary rat hepatocytes [Kapoor \& Kakkar, 2012].

Additionally, long term high-fat feeding initiated dyslipidemia and ROS generation in the HFD/STZ-induced diabetic mouse model. Phenolic compounds of MVR, likewise in the previous study concerning vanillic acid [Chang et al., 2015] and phenolic-rich extract of white ginseng [Lee et al., 2013], showed hypolipidemic and antioxidant 
TABLE 4. Effect of mangosteen vinegar rind (MVR) on oxidative stress markers and antioxidant levels of mice model.

\begin{tabular}{l|c|c|c|c|c}
\hline \multirow{2}{*}{ Group } & \multicolumn{2}{|c|}{ Plasma } & \multicolumn{3}{c}{ Liver tissue } \\
\cline { 2 - 6 } & $\begin{array}{c}\text { Bilirubin } \\
(\mathrm{mg} / \mathrm{dL})\end{array}$ & $\begin{array}{c}\text { MDA } \\
(\mathrm{nM} / \mathrm{ml})\end{array}$ & $\begin{array}{c}\text { MDA } \\
(\mathrm{nM} / \mathrm{g} \text { protein })\end{array}$ & $\begin{array}{c}\text { SOD } \\
(\mathrm{U} / \mathrm{g} \text { Protein) }\end{array}$ & $\begin{array}{c}\text { CAT } \\
(\mathrm{K} / \mathrm{mg} \text { protein })\end{array}$ \\
\hline Normal control & $0.51 \pm 0.08$ & $2 \pm 0.1$ & $35 \pm 2.8$ & $64 \pm 8.6$ & $85 \pm 5.4$ \\
Diabetic control & $0.22 \pm 0.02^{\mathrm{a}}$ & $7 \pm 0.3^{\mathrm{a}}$ & $183 \pm 3.6^{\mathrm{a}}$ & $22 \pm 2.5^{\mathrm{a}}$ & $27 \pm 3.4^{\mathrm{a}}$ \\
DM+MVR 100 mg/kg BW & $0.31 \pm 0.04$ & $4 \pm 0.3^{\mathrm{a}, \mathrm{b}}$ & $118 \pm 8.3^{\mathrm{a}, \mathrm{b}}$ & $26 \pm 7.2^{\mathrm{a}}$ & $51 \pm 4.2^{\mathrm{a}, \mathrm{b}}$ \\
DM+MVR 200 mg/kg BW & $0.33 \pm 0.03^{\mathrm{b}}$ & $3 \pm 0.2^{\mathrm{a}, \mathrm{b}, \mathrm{c}}$ & $74 \pm 8.7^{\mathrm{a}, \mathrm{b}, \mathrm{c}}$ & $40 \pm 4.2^{\mathrm{b}}$ & $67 \pm 2.8^{\mathrm{b}, \mathrm{c}}$ \\
DM+glibenclamide 60 mg/kg BW & $0.46 \pm 0.04^{\mathrm{b}}$ & $2 \pm 0.2^{\mathrm{b}}$ & $56 \pm 7.6^{\mathrm{a}, \mathrm{b}}$ & $55 \pm 5.0^{\mathrm{b}}$ & $77 \pm 1.5^{\mathrm{b}}$ \\
\hline
\end{tabular}

DM - diabetic mice; MDA - malondialdehyde; SOD - superoxide dismutase; CAT - catalase. Data are expressed as mean \pm SEM $(n=6)$. ${ }^{a} P<0.05$ versus Normal control; ${ }^{\mathrm{b}} P<0.05$ versus Diabetic control; ${ }^{\mathrm{c}} \mathrm{P}<0.05$ versus MVR-treated at dose $100 \mathrm{mg} / \mathrm{kg} \mathrm{BW}$.

properties and were reducing hyperlipidemic markers (TC, TG, LDL), and increasing plasma HDL levels. Moreover, the oxidative stress marker (MDA) and activity of antioxidant enzymes SOD and CAT were improved. Consequently, we found that MVR significantly $(P<0.05)$ ameliorated the plasma and hepatic lipid profile (Table 2) and oxidative damage (Table 4) in the HFD/STZ-induced diabetic type II model $(P<0.05)$ compared to the untreated diabetic control group. We also found that MVR increased the glycogen content in the liver tissue of HFD/STZ diabetic mice indicating increased insulin sensitivity. High glucose levels were stored in the liver and muscle tissue with the help of insulin using a glucose transporter. As a result, the hepatic glycogen content in the HFD/STZ-induced diabetic control group significantly reduced $(P<0.05)$ compared to the normal control group, which was indicative of tissue insulin resistance [Bhandari et al., 2013]. Treatment with MVR and glibenclamide would be able to restore glycogen content indicating tissue glucose uptake and hepatic glucose production [Moore et al., 2012].

Furthermore, AST and ALT, the enzymatic markers of liver cell damage, showed increased activity under these type II diabetic conditions compared to the normal control group. Furthermore, the plasma total bilirubin followed the same pattern with the hepatotoxic enzymatic markers (AST and ALT) and antioxidant enzyme markers (SOD, CAT); though all the values were within the normal range (Table 4). MVR-treated HFD/STZ diabetic mice showed higher bilirubin levels than the non-treated HFD/STZ diabetic mice. Recently, bilirubin levels have been reported to increase insulin sensitivity by regulating metabolism and reducing cholesterol level [Liu et al., 2015]. Increased bilirubin levels are associated with the antioxidant enzyme hemeoxygenase-1 activity and may explain the versatile cellular protection [McCarty et al., 2013]. Taken together, MVR may be able to improve liver function by maintaining the AST and ALT levels, and improving bilirubin levels with complicated type II diabetic patients and our HFD/STZ-induced diabetes type II model [Idris et al., 2011]. The present study provides evidence that MVR acts as a hepatoprotective agent against oxidative damage, which is at least partly due to its phenolic compounds and antioxidant capacity.

\section{CONCLUSION}

In the present study we evaluated the anti-glycemic and anti-hepatotoxic effects of MVR. We used glibenclamide as a standard to compare the anti-glycemic and anti-hepatotoxic effects of MVR on diabetic mice. MVR from Garcinia mangostana and glibenclamide treatments improved the levels of glucose, hepatic glycogen, lipid profile, oxidative stress, antioxidant enzyme activity and liver function biomarkers of HFD/STZ-induced type II diabetic mouse models compared to untreated diabetic control group. Besides this, MVR high dose showed comparatively potent effects than the MVR low dose. The presence of phenolic compound in MVR extract exhibited antioxidant capacity, evaluated by in vitro study. It can protect tissues from cellular oxidative damage by scavenging hyperglycemia-induced free radicals and improve tissue glucose uptake. MVR may be a potential dietary supplement for hyperglycemia and hyperlipidemia patients. Further studies are still needed to clarify the underlying mechanisms.

\section{RESEARCH FUNDING}

This study was supported by the Thailand Toray Science Foundation (TTSF) Research Grants and in part by the Walailak University, Thailand.

\section{CONFLICT OF INTERESTS}

All authors declare no conflict of interest.

\section{REFERENCES}

1. Bennett L.W., Keirs R.W., Peebles E.D., Gerard P.D., Methodologies of tissue preservation and analysis of the glycogen content of the broiler chick liver. Poult. Sci., 2007, 86, 2653-2665.

2. Berdja S., Smail L., Saka B., Neggazi S., Haffaf E., Benazzoug Y., Kacimi G., Boudarene L., Bouguerra S.A., Glucotoxicity induced oxidative stress and inflammation in vivo and in vitro in Psammomys obesus: involvement of aqueous extract of Brassica rapa rapifera. Evid. Based Complement. Altern. Med., 2016, 2016, art. No. 3689208. 
3. Bhandari U., Chaudhari H.S., Khanna G., Najmi A.K., Antidiabetic effects of Embelia ribes extract in high fat diet and low dose streptozotocin-induced type 2 diabetic rats. Front Life Sci., 2013, 7, 186-196.

4. Bligh E.G., Dyer W.J., A rapid method of total lipid extraction and purification. Can. J. Biochem. Physiol., 1959, 37, 911-917.

5. Bonnefont-Rousselot D., Glucose and reactive oxygen species. Curr. Opin. Clin. Nutr. Metab. Care, 2002, 5, 561-568.

6. Carr T.P., Andresen C.J., Rudel L.L., Enzymatic determination of triglycerides, free cholesterol and total cholesterol in tissue lipid extracts. Clin. Biochem., 1993, 26, 39-42.

7. Ceci R., Valls M.R.B., Durantin G., Dimauro I., Quaranta F., Pittaluga M., Sabatini S., Caserotti P., Parisi P., Parisi A., Caporossia D., Oxidative stress responses to a graded maximal exercise test in older adults following explosive-type resistance training. Redox Biol., 2014, 2, 65-72.

8. Chang W.C., Wu J.S.B., Chen C.W., Kuo P.L., Chien H.M., Wang Y.T., Shen S.C., Protective effect of vanillic acid against hyperinsulinemia, hyperglycemia and hyperlipidemia via alleviating hepatic insulin resistance and inflammation in high-fat diet (HFD)fed rats. Nutrients, 2015, 7, 9946-9959.

9. Cordero-Herrera I., Martin M.A., Goya L., Ramos S., Cocoa flavonoids protect hepatic cells against high-glucose-induced oxidative stress: relevance of MAPKs. Mol. Nutr. Food Res., 2015, 59, 597-609.

10. Das J., Sil P.C., Taurine ameliorates alloxan-induced diabetic renal injury, oxidative stress-related signaling pathways and apoptosis in rats. Amino Acids, 2012, 43, 1509-1523.

11. Elgawish R.A.R., Rahman H.G.A., Abdelrazek H.M.A., Green tea extract attenuates $\mathrm{CCl}_{4}$-induced hepatic injury in male hamsters via inhibition of lipid peroxidation and p53-mediated apoptosis. Toxicol. Rep., 2015, 2, 1149-1156.

12. Gilbert E.R., Fu Z., Liu D., Development of a nongenetic mouse model of type 2 diabetes. Exp. Diab. Res., 2011, 2011, 416254.

13. Goulart M., Batoreu M.C., Rodrigues A.S., Laires A., Rueff J., Lipoperoxidation production and thiol antioxidant in chromium exposed worker. Mutagenesis, 2005, 20, 311-315.

14. Idris A.S., Mekky K.F.H., Abdalla B.E.E., Ali K.A., Liver function tests in type 2 Sudanese diabetic patients. Int. J. Nutr. Metab., 2011, 2, 17-21.

15. Ismail N.S., Protective effects of aqueous extracts of cinnamon and ginger herbs against obesity and diabetes in obese diabetic rat. World J. Dairy Food Sci., 2014, 9, 145-153.

16. Jarukamjorn K., Lao-ong T., Chatuphonprasert W., Diabetic induction in experimental mouse model. Thai Pharm. Health Sci J., 2011, 6, 229-39, [http://ejournals.swu.ac.th/index.php/ pharm/article/view/2463/2481].

17. Kaisoon O., Siriamornpun S., Weerapreeyakul N., Meeso N., Phenolic compounds and antioxidant activities of edible flowers from Thailand. J. Funct. Foods, 2011, 3, 88-99.

18. Kapoor R., Kakkar P., Protective role of morin, a flavonoid, against high glucose induced oxidative stress mediated apoptosis in primary rat hepatocytes. PLoS One, 2012, 7, 41663.

19. Lee L.S., Cho C.W., Hong H.D., Lee Y.C., Choi U.K., Kim Y.C., Hypolipidemic and antioxidant properties of phenolic compound-rich extracts from white ginseng (Panax ginseng) in cholesterol-fed rabbits. Molecules, 2013, 18, 12548-12560.

20. Li X., Xu Z., Jiang Z., Sun L., Ji J., Miao J., Zhang X., Li X., Huang S., Wang T., Zhang L., Hypoglycemic effect of catalpol on high-fat diet/streptozotocin-induced diabetic mice by increasing skeletal muscle mitochondrial biogenesis. Acta Biochim. Biophys. Sin., 2014, 46, 738-748.

21. Lim Y.S., Lee S.S.H., Tan B.C., Antioxidant capacity and antibacterial activity of different parts of mangosteen (Garcinia mangostana Linn.) extracts. Fruits, 2013, 68, 483-489.

22. Liu J., Dong H., Zhang Y., Cao M., Song L., Pan Q., Bulmer A., Adams D.B., Dong X., Wanga H., Bilirubin increases insulin sensitivity by regulating cholesterol metabolism, adipokines and PPAR $\gamma$ levels. Sci. Rep., 2015, 5, 9886.

23. Marklund S., Marklund G., Involvement of the superoxide anion radical in the autooxidation of pyrogallol and a convenient assay for superoxide dismutase. Eur. J. Biochem., 1974, 47, 469-474.

24. Masuko T., Minami A., Iwasaki N., Majima T., Nishimura S., Lee Y.C., Carbohydrate analysis by a phenol-sulfuric acid method in microplate format. Anal. Biochem., 2005, 339, 69-72.

25. McCarty M.F., Serum bilirubin may serve as a marker for increased heme oxygenase activity and inducibility in tissues--a rationale for the versatile health protection associated with elevated plasma bilirubin. Med. Hypotheses, 2013, 81, 607-610.

26. Miralles-Linares F., Puerta-Fernandez S., Bernal-Lopez M.R., Tinahones F.J., Andrade R.J., Gomez-Huelgas R., Metformin-induced hepatotoxicity. Diab. Care, 2012, 35, 21.

27. Moore M.C., Coate K.C., Winnick J.J., An Z., Cherrington A.D., Regulation of hepatic glucose uptake and storage in vivo. Adv. Nutr., 2012, 3, 286-294.

28. Nguyen P., Leray V., Diez M., Serisier S., Bloc'h J.L., Siliart B., Dumon H., Liver lipid metabolism. J. Anim. Physiol. Anim. Nutr. (Berl)., 2008, 92, 272-283.

29. Pandey A., Tripathi P., Pandey R., Srivatava R., Goswami S., Alternative therapies useful in the management of diabetes: a systematic review. J. Pharm. Bioallied Sci., 2011, 3, 504-512.

30. Pandey K.B., Rizvi S.I., Plant polyphenols as dietary antioxidants in human health and disease. Oxid. Med. Cell Longev., 2009, 2, 270-278.

31. Phyu M.P., Tangpong J., Neuroprotective effects of xanthone derivative of Garcinia mangostana against lead-induced acetylcholinesterase dysfunction and cognitive impairment. Food Chem. Toxicol., 2014, 70, 151-156.

32. Ramesh B., Sainath S.B., Karuna R., Sreenivasa Reddy S., Manjunatha B., Sudhakara G., Sasi Bhusana Rao B., Saralakumari D., Effect of Commiphora mukul gum resin on hepatic and renal marker enzymes, lipid peroxidation and antioxidants status in pancreas and heart in fructose fed insulin resistant rats. BeniSuef Univ. J. Basic Appl. Sci., 2015, 4, 269-278.

33. Re R., Pellegrini N., Proteggente A., Pannala A., Yang M., Rice-Evans C., Antioxidant activity applying an improved ABTS radical cation decolorization assay. Free Radic. Biol. Med., 1999, 26, 1231-1237.

34. Sattayasai J., Chaonapan P., Arkaravichie T., Soi-ampornkul R., Junnu S., Charoensilp P., Samer J., Jantaravinid J., Masaratana P., Suktitipat B., Manissorn J., Thongboonkerd V., Neungton N., Moongkarndi P., Protective effects of mangosteen extract on $\mathrm{H}_{2} \mathrm{O}_{2}$-induced cytotoxicity in SK-N-SH cells and scopolamineinduced memory impairment in mice. PLoS One, 2013, 8, 85053.

35. Sherwin R.S., Role of liver in glucose homeostasis. Diab. Care, 1980, 3, 261-265.

36. Sivakrishnan S., Kottaimuthu A., Hepatoprotective activity of ethanolic extract of aerial parts of Albizia procera roxb (Benth.) 
against paracetamol induced liver toxicity on wistar rats. Int. J. Pharm. Sci., 2014, 6, 233-238.

37. Suriyamoorthy P., Mary M.R.F., Subrhamanian H., Kanagasapabathy D., Protective activity of aqueous leaf extracts of Aegle marmelos and Camellia sinensis in oil induced dyslipidemic rats. World J. Pharm. Sci., 2014, 3, 1568-1580.

38. Takahara S., Hamilton H.B., Nell J.V., Kobra T.Y., Ogura Y., Nishimura E.T., Hypocatalasemia: a new genetic carrier state. J. Clin. Invest., 1960, 39, 610-619.

39. Van den Berghe G., Wilmer A., Hermans G., Meersseman W., Wouters P.J., Milants I., Van Wijngaerden E., Bobbaers H., Bouil- lon R., Intensive insulin therapy in the medical ICU N. Engl. J. Med., 2006, 354, 449-461.

40. Wilcox G., Insulin and insulin resistance. Clin. Biochem. Rev., 2005, 26, 19-39.

41. World Health Organization (WHO), Global report on diabetes (Diabetes Mellitus-epidemiology), 2016, Geneva.

Submitted: 6 October 2016. Revised: 13 February and 17 March 2017. Accepted: 27 April 2017. Published on-line: 6 November 2017. 